Creative Commons User License: CC BY-NC-ND

Abstracted by: EBSCOhost, Electronic Journals Service (EJS), Google Scholar, Journal Seek, Scientific Commons,

Food and Agricultural Organization (FAO), CABI and Scopus
Journal of Agricultural Extension

Vol. 23 (3) July, 2019

ISSN(e): 24086851; ISSN(Print); 1119944X

http://journal.aesonnigeria.org

http://www.ajol.info/index.php/iae

Email: editorinchief@aesonnigeria.org

\title{
Challenges of Youths Involved in Fish Farming in the Federal Capital Territory, Abuja, Nigeria
}

https://dx.doi.org/10.4314/jae.v23i3.14

\section{Ifeonu, Chidimma. Frances}

Department of Agricultural Extension,

University of Nigeria, Nsukka.

E-mail: phrancesleaticia@gmail.com

Phone: +234 -7037085498

\section{Chukwuemeka, Victory}

Department of Agricultural Extension,

University of Nigeria, Nsukka.

E-mail: chukwuemeka.victory.c@gmail.com

\section{Agwu Ekwe Agwu}

Department of Agricultural Extension,

University of Nigeria, Nsukka.

E-mail: ekwe.agwu@unn.edu.ng

Phone: +234-8034024251

\section{Abstract}

This study determined the challenges of youths involved in fish farming in the Federal Capital Territory, Abuja, Nigeria. Multi-stage sampling procedure was used to select and interview a total of 54 youth fish farmers'from18 villages in three area councils of the FCT, Abuja. Results of the analysis were presented using percentage, frequency counts, and mean scores. Results reveal that majority (57.4\%) of the respondents had fish farming as their major occupation. The majority (87\%) of respondents adopted the monoculture system of fish production. However, the major challenges faced by the youths were high cost of feed $(\bar{x}=2.76)$ and poor access to credit facilities $(\bar{x}=2.17)$. The farmers' perceived

solutions to the challenges were access to loans and grants, provision of feed subsidy, access to affordable land, provision of infrastructure (such as good roads, better markets, and better power supply), proper training of fish farmers on management practices, increased research and extension services. The study points to the need for public-private partnership intervention geared towards improving the entrepreneurial drive of the youths through focused training and other empowerment activities to enable them address the challenges facing fish farmers in the area.

Keyword: Youth fish farming, federal capital territory Abuja

\section{Introduction}

In Nigeria, the role of fish farming in achieving household and national food security and poverty alleviation cannot be over emphasized. Fish farming which refers to an artificial method of raising fish for human consumption provides profitable means of livelihood for both rural and urban dwellers. It involves some form of intervention in the rearing process to 
Creative Commons User License: CC BY-NC-ND

Abstracted by: EBSCOhost, Electronic Journals Service (EJS), Google Scholar, Journal Seek, Scientific Commons,

Food and Agricultural Organization (FAO), CABI and Scopus
Journal of Agricultural Extension

Vol. 23 (3) July, 2019

ISSN(e): 24086851; ISSN(Print); 1119944X

http://journal.aesonnigeria.org

http://www.ajol.info/index.php/iae

Email: editorinchief@aesonnigeria.org

enhance production, such as regular stocking, feeding, protection from predators, etc. With an estimated annual per caput fish consumption of $13.3 \mathrm{~kg}$ in 2013, fish represents an important dietary element and one of the few sources of animal protein and white meat available to many Nigerians (Food and Agriculture Organization (FAO), 2017). Fish is very nutritious, providing a good source of high quality protein and other essential nutrients, which are especially important for mothers and growing children. It is low in cholesterol and calories levels, but rich in protein (Ryota, Munehiro, and Kenji. 2012).

Nigeria is a typical coastal country highly endowed with large rivers, small water bodies and some natural springs with both fresh and marine fishery resources (Dimelu, Ifeonu, Asadu and Ayogu, 2018). The country is blessed with over 14 million ha of reservoirs, lakes, ponds, and major rivers capable of producing over 980,000 metric tons of fish annually (Oladimeji, 2017). According to National Bureau of Statistics (NBS) (2017), Nigeria's fish production data showed that 5,788,474 tons of fish had been produced between 2010 and 2015. The year 2014 recorded the highest tons of fish produced with 1,123,011 tons; the second highest tons of fish produced were recorded in 2015 while the least were recorded in 2010.Therefore, it can be concluded that Nigeria is endowed with abundant fishery resources to produce enough fish and fish products not only for domestic consumption but also for export.

However, in spite of the great potentials of fish farming in Nigeria, Nigeria is still unable to bridge the gap in the shortfall between total domestic fish production and total domestic demand. According to Food and Agriculture Organization (FAO) (2019), total domestic fish production is far less than the total domestic demand. According to Fishery Committee for the West Central Gulf of Guinea (FCWC), (2016), the total fish demand for Nigeria based on the 2014 population estimate of $180 \mathrm{~m}$ is $3.32 \mathrm{~m}$ Mt. Food and Agriculture Organization (2018), observed that even though Nigeria is regarded among major producing nations of aquaculture in Africa, producing about 307,000 tons of fish, this is negligible compared to the projected yields estimated at two million tons. This implies that in order to meet the FAO requirement of 12.5 kilograms per head per annum, Nigeria imports about 1.2 million tons of fish to satisfy basic protein needs of her citizens (FAO, 2019).

One of the problems for the non-realization of the goal of food sufficiency is the condition of the Nigerian farmers and farming environment (Adelodun, Bankole, Rafiu, Marawo and Ajao, 2016). The Nigerian farmer is ageing with an average age of 50 years (Adelodun et. al. 2016). The agricultural future of the nation may be bleak if the bulk of the production efforts are left in the hands of aged subsistent farmers who presently constitute the major farming population. The productivity level of the aged farmers cannot meet the food and fibre needs of the rapidly growing population and they will definitely phase out on the account of age.

Fish farming in the country is still carried out with some physical strength which the already ageing farmers do not possess. The youth are a particular portion of a nation's population that is sensitive, energetic and active and are in their most productive phase of life as citizens (Furlong, 2013). According to NBS 2018, the growing share of the overall population in Nigeria is made up of those considered to be of working age and thus not 
Creative Commons User License: CC BY-NC-ND

Abstracted by: EBSCOhost, Electronic Journals Service (EJS), Google Scholar, Journal Seek, Scientific Commons,

Food and Agricultural Organization (FAO), CABI and Scopus
Journal of Agricultural Extension

Vol. 23 (3) July, 2019

ISSN(e): 24086851; ISSN(Print); 1119944X

http://journal.aesonnigeria.org

http://www.ajol.info/index.php/iae

Email: editorinchief@aesonnigeria.org

dependent on the economic activity of others. This shows that the youth dominates the country in terms of population. Youths have desirable qualities that can promote all the subsectors of agriculture but most of them have strong apathy towards it (Adelodun, 2015). Rather than getting involved in farming activities, a vast population of the youth go in search of the white collar jobs. Presently, it has been observed that the number of youth involved in aquaculture is very small (Adelodun, 2015). The over-all effect of this scenario is that more Nigerians will continue to be protein deficient today and resources that could be used to improve our infrastructure will continually be spent on importation of fish into the country. For fish farming to reach its full potential there should be a considerable and active participation of a high percentage of the youth in the sector.

However, with the numerous challenges faced by the youths currently involved in fish farming in the country the sector is being neglected with preference to white collar jobs which are on the other hand getting more and more unavailable as the days go by. Also, the present fish farming environment makes it even more difficult to explore their full potential in fishery production in order to stimulate the interest of the youth. There is therefore a compelling need to boost and sustain youth's interest and participation in aquaculture activities.

Thus, this study will be guided with the following questions: What are the fish species cultivated in the area? What fish production system(s) do the youth adopt? What are the management practices of the fish farmers? What are the challenges faced by the fish farmers in the course of production? What are the perceived solutions to these challenges? The overall purpose of the study was to determine the challenges of youths involved in fish farming in the Federal Capital City, Abuja. Specifically, the study sought to:

1. identify the major species of fish farmed in the study area;

2. ascertain the management practices of the fish farmers;

3. identify the major challenges of the fish farmers; and

4. ascertain the perceived solution to these challenges.

\section{Methodology}

The study was carried out in the federal capital territory, Abuja. The city is located in the centre of Nigeria. It shares boundaries with Kaduna state to the north, Kogi state to the south-west, Niger state to the west and Nasarawa state to the east. It straddles on latitude $9^{\circ} 4^{\prime} \mathrm{N}$ and longitude $7^{\circ} 29^{\prime} \mathrm{E}$ of the equator. The city occupies an area of about 8,000 sq km. As at the 2006 census, the city of Abuja had a population of about 776,298 (National Population Commission, 2006), making it one of the ten most populous cities in Nigeria. The city is made of six (6) area councils namely; Abaji, Abuja Municipal, Bwari, Gwagwalada, Kuje and Kwali Area Councils.

The six area councils (Abaji, Abuja Municipal, Bwari, Gwagwalada, Kuje and Kwali) made up the population for the study. Multi-stage sampling technique was used to select the respondents. In the first stage, three (3) area councils (Bwari, Abuja Municipal and Kuje) were purposively selected from the six area councils in Abuja based on their popularity in fish farming. In the second stage, three (3) town communities dominated by fish farmers were selected from the 3 area councils, giving a total of nine (9) town communities. In the 
Creative Commons User License: CC BY-NC-ND

Abstracted by: EBSCOhost, Electronic Journals Service (EJS), Google Scholar, Journal Seek, Scientific Commons,

Food and Agricultural Organization (FAO), CABI and Scopus
Journal of Agricultural Extension

Vol. 23 (3) July, 2019

ISSN(e): 24086851; ISSN(Print); 1119944X

http://journal.aesonnigeria.org

http://www.ajol.info/index.php/iae

Email: editorinchief@aesonnigeria.org

third stage, two (2) villages were selected, giving a total of 18 villages. Three youths were selected from each village using snow ball sampling technique, giving a total of 54 respondents for the study.

Institutional characteristics such as membership in organisation/associations, access to credit facilities, sources of information on fish farming, extension contacts, formal training were measured at nominal and ordinal levels. To identify farmers' production characteristics and management practices on fish farming, a list of options on production characteristics and management practices was provided to the farmers to tick on the appropriate option. To determine major challenges faced by fish farmers, a three-point Likert- type scale with response options of very serious $=3$, serious $=2$ and not serious $=1$ was used. The cut-off mean was 2 . Variables with mean scores above 2 were regarded as serious challenges, while those with mean scores of less than 2 were regarded as not serious challenges. Data for this study were collected using structured interview schedule and analysed using percentage and mean scores.

\section{Results and Discussion}

\section{Institutional Characteristics}

The majority $(64.8 \%)$ of the respondents belonged to one social/religion organization or the other and a greater proportion (57.1\%) belonged to cooperative society and farmers' association (Table 1). These organizations according to Ojiagu, Onugu \& Uchenna (2015), could serve as channels for contact with larger members of other practitioners, as these offer opportunities for participatory interaction with extension organizations.

Majority (50\%) of the respondents asserted that they had access to credit facilities. Funds and credit play vital roles in enhancing productivity. A majority $(87.0 \%)$ of the respondents began by using personal funds such as savings or sales, while $13.0 \%$ got funds from farmers' association. This means that farmers depend mostly on informal sources of credit. This could be due to the fact most banks and other credit institutions attract high interest rates and most farmers have no collateral (Akinnagbe and Adonu, 2014).

A majority $(77.8 \%)$ of respondents got information on fish farming through the internet and this confirms the high literacy level of the respondents and probably sound knowledge of modern technology. Table1further show that the mean number of times extension agents visited the respondents was 2 times. This implies that extension activities in the study area are very poor and could partly explain why majority of the respondents' sourced information from the internet. The mean number of times the respondents received training was 2 times. This is very poor and might be due to high cost of acquiring formal training on the business leaving the farmers to depend on informal training from relations, other farmers, cooperatives. 
Creative Commons User License: CC BY-NC-ND

Abstracted by: EBSCOhost, Electronic Journals Service (EJS),

Google Scholar, Journal Seek, Scientific Commons,

Food and Agricultural Organization (FAO), CABI and Scopus

http://eoi.citefactor.org/10.11226/v23i3
Journal of Agricultural Extension

Vol. 23 (3) July, 2019

ISSN(e): 24086851; ISSN(Print); 1119944X

http://journal.aesonnigeria.org

http://www.ajol.info/index.php/jae Email: editorinchief@aesonnigeria.org

Table 1: Institutional characteristics

\begin{tabular}{|c|c|c|}
\hline Institutional characteristics & Percentage (\%) & Mean \\
\hline \multicolumn{3}{|c|}{ Membership in organisations/associations } \\
\hline Yes & 64.8 & \\
\hline \multicolumn{3}{|c|}{ Number of organisations belonged to } \\
\hline 1 & 51.4 & \\
\hline 2 & 40.0 & 2 \\
\hline 3 & 5.7 & \\
\hline 4 & 2.9 & \\
\hline \multicolumn{3}{|l|}{ Organisation belonged to* } \\
\hline Trader organisation & 37.1 & \\
\hline Cooperative society & 57.1 & \\
\hline Farmers association & 57.1 & \\
\hline Religious group & 2.9 & \\
\hline Research group & 2.9 & \\
\hline \multicolumn{3}{|l|}{ Access to credit facilities } \\
\hline Yes & 50.0 & \\
\hline \multicolumn{3}{|l|}{ Sources of funds* } \\
\hline Personal & 87.0 & \\
\hline Relatives & 16.7 & \\
\hline Cooperative/thrift society & 22.2 & \\
\hline Credit institutions & 22.2 & \\
\hline Farmers association & 13.0 & \\
\hline \multicolumn{3}{|l|}{ Sources of information* } \\
\hline Magazine/bulletin & 14.8 & \\
\hline Newspaper & 1.9 & \\
\hline Internet & 77.8 & \\
\hline Fellow fish farmers & 20.4 & \\
\hline TV/radio & 13.0 & \\
\hline Extension workers & 16.7 & \\
\hline Cooperative meetings & 1.9 & \\
\hline \multicolumn{3}{|l|}{ Extension visits } \\
\hline Yes & 51.9 & \\
\hline \multicolumn{3}{|l|}{ Number of extension visits } \\
\hline $1-3$ & 67.9 & \\
\hline $4-6$ & 21.4 & \\
\hline $7-9$ & 7.1 & 2 \\
\hline $10-12$ & 3.6 & \\
\hline \multicolumn{3}{|l|}{ Formal training received } \\
\hline Yes & 72.2 & \\
\hline \multicolumn{3}{|l|}{ Number of times received training } \\
\hline $1-5$ & 94.9 & 2 \\
\hline $6-10$ & 5.1 & \\
\hline \multicolumn{3}{|l|}{ Areas training was received ${ }^{\star}$} \\
\hline Daily pond management & 52.3 & \\
\hline Fish feeding & 48.7 & \\
\hline Fish handling and transportation & 7.7 & \\
\hline Fish breeding & 66.7 & \\
\hline Processing and storage & 23.1 & \\
\hline Disease and health management & 41.0 & \\
\hline Use and storage of chemicals & 2.6 & \\
\hline Marketing and distribution & 23.1 & \\
\hline Feed formulation & 33.3 & \\
\hline
\end{tabular}

*Multiple responses 
Creative Commons User License: CC BY-NC-ND

Abstracted by: EBSCOhost, Electronic Journals Service (EJS),

Google Scholar, Journal Seek, Scientific Commons,

Food and Agricultural Organization (FAO), CABI and Scopus
Journal of Agricultural Extension

Vol. 23 (3) July, 2019

ISSN(e): 24086851; ISSN(Print); 1119944X

http://journal.aesonnigeria.org

http://www.ajol.info/index.php/iae

Email: editorinchief@aesonnigeria.org

\section{Production Practices}

Table 2 shows that the majority (87.0\%) of the respondents adopted the monoculture system of fish farming; while $7.4 \%$ adopted integrated culture system and $5.6 \%$ adopted the polyculture system of fish farming. Monoculture is the practice of producing only one species of fish in fish farming structures (pond or tank). Polyculture is the production of two or more fish species within a particular aquaculture environment (in the same pond). Keeping fish with different diets in the same space increases the net yield of the pond and the value of production while integrated fish farming is a type of polyculture where a farmer could have several sub-systems of agriculture around his/her fish pond. It is a process of farming where fishes are produced in combination with other farm products and livestock, cantered around the fish farm. This leads to greater overall efficiency of the farming system as wastes/by-products or one component are used as inputs in another. For example, poultry or pig manure can be used to fertilize the fish pond and the vegetable garden and the waste vegetables can be fed to the fish and the pigs.

The appealing factor for farmers in adopting the monoculture system of fish farming is the apparent simplicity and uniformity of monoculture as it is much easier and straightforward to breed one type of animal in terms of the knowledge and experience needed to do it successfully. This gives farmers more space to improve their system based on their experience, as they have time to observe what system works the best for the fishes. It is also easy to monitor individual fish breed performance using this system.

The fish species cultured in the study area were Clariasgariepinus (African catfish), Heterobranchus spp (Sampa catfish), Heteroclarias spp (a hybrid of Clariasgariepinus and Heterobranchus spp), Tilapia spp (tilapia) and Cyprinuscarpio (carp). However, the major specie farmed in the area is Clariasgariepinus (85.2\%) which is the African catfish. This could be because of its high market demand, fast growth rate, high adaptation, ease of rearing, high preference, good marketability, good feed conversion rate, high resistance to diseases, low mortality rate and the fact that they can survive in both running and stagnant water. Besides, most recent investment in aquaculture has been targeted towards catfish farming and currently, about $90 \%$ of farmed fish in Nigeria is catfish which is now a major attraction to private sector investors in Nigeria (Oyedeji, 2016). Presently, live catfish attracts premium price in Nigeria with a high return of investment ranging between $40-60 \%$ in some very successful enterprise (Keremah and Esquire, 2014).

On the reasons for selecting the above species in the study area, majority $(61.1 \%)$ farmed the species because of their high market demand and also because of their fast growth $(53.7 \%)$ and high adaptation (25.9\%). The high demand of these species could be because it is regarded as important diet and protein source. In terms of fast growth rate, they mature very fast and reach market size within relatively short time and they are highly adaptable. They can eat almost anything they can find in nature, they can survive and grow in brackish and low oxygen water and can tolerate high density.

Table 2 also shows that a majority (75.9\%) of the respondents use earthen ponds, while $35.2 \%$ use concrete ponds. The high use of earthen ponds suggests that it is easier to 
Creative Commons User License: CC BY-NC-ND

Abstracted by: EBSCOhost, Electronic Journals Service (EJS), Google Scholar, Journal Seek, Scientific Commons,

Food and Agricultural Organization (FAO), CABI and Scopus
Journal of Agricultural Extension

Vol. 23 (3) July, 2019

ISSN(e): 24086851; ISSN(Print); 1119944X

http://journal.aesonnigeria.org

http://www.ajol.info/index.php/iae

Email: editorinchief@aesonnigeria.org

use, reduces the stress of changing water frequently and less expensive to construct. Earthen pond culture system has been the conventional method of fish culture in Nigeria, until recently when it started giving way to the use of concrete tanks culture system as land become costly, scarce and not readily available (Njoku, Agwa and Ibiene, 2014). The disadvantages associated with earthen pond is that some invertebrate (e.g tubifex) living in the soil and serving as intermediate hosts for parasites (Myxoboluscerebralis) and disease outbreaks (whirling disease) are only seen in earthen ponds. Treatment is often very difficult due to high organic load that inactivates part of the active ingredients of the product. The turbidity also hampers the observation of the fish and early signs of the disease may not be registered. Hygiene is difficult and eggs or developing stages of parasites can hardly be removed.

A majority (65\%) of the respondents chose their pond types because they are easy and less expensive to construct, $44.4 \%$ chose their pond types because they are easy to maintain, $22.2 \%$ chose their pond types because of their high stocking density and $20.4 \%$ chose their pond types because they require less space for construction. Also, Table 5 shows that majority $(75.9 \%)$ of the respondents had less than 10 ponds and the mean number of ponds was 7 . This implies that production is at full potential in the area. Igwe and Mgbaja (2014) reported that to attain the full potential of pond fish production the operators should have more than 3 ponds that are being manage

Furthermore, result in Table 2 shows that of those that apply fertilizer, $55.2 \%$ of the respondents use cow manure to fertilize their ponds, while $44.8 \%$ use poultry manure to fertilize their ponds. Liming is done mainly to reduce acidity of water in fish ponds (Bolonmduro, 2013). Results presented in Table 2 indicate that a large proportion (68.5\%) of the respondents lime their ponds with limestone. This implies that the majority of the water bodies in the study area is relatively acidic and the use of limestone against caustic lime and quick lime might be because limestone is the cheapest and most readily available liming ingredient in the area. Most $(64.8 \%)$ of the respondents depended on natural sources of water where the main sources of water for their farming was streams/rivers, $44.4 \%$ depended on boreholes and $7.4 \%$ got water from wells. This indicates the relative abundance of water bodies in the study area. The reason for greater usage of rivers / stream could be because it is readily available in large volumes, inexpensive and well oxygenated. However, the near high dependence of respondents on borehole is because it is a self-sufficient water source unlike natural sources that are not reliable, dries up during droughts and contains excessive nutrients, contaminates or predators. Also the water quality from borehole is invariably high as it retains a more consistent temperature which is devoid of pollution, predatory insects or pathogens though it contains dissolved gases like nitrogen, carbon dioxide and low to no dissolved oxygen. In addition, the respondents complained of the pumping cost in the use of boreholes as they make use of generator and fuel due to epileptic power supply in the area. 
Creative Commons User License: CC BY-NC-ND

Abstracted by: EBSCOhost, Electronic Journals Service (EJS), Google Scholar, Journal Seek, Scientific Commons,

Food and Agricultural Organization (FAO), CABI and Scopus
Journal of Agricultural Extension

Vol. 23 (3) July, 2019

ISSN(e): 24086851; ISSN(Print); 1119944X

http://journal.aesonnigeria.org

http://www.ajol.info/index.php/jae Email: editorinchief@aesonnigeria.org

Table 2: Production practices

\begin{tabular}{lll}
\hline Production practices & Percentage (\%) & Mean \\
\hline Culture system & \\
Monoculture & 87.0 \\
Polyculture & 5.6 \\
Integrated culture & 7.4 \\
Species of fish farmed & \\
Clariasgariepinus (catfish) & 85.2 \\
Heterobranchusspp (Sampacattish) & 25.9 \\
Heteroclariasspp (hybridcatfish) & 14.8 \\
Cyprinuscarpio (carp) & 3.7 \\
Tilapia spp (tilapia) & 25.9 \\
Reason for selecting species & \\
Fast growth & 53.7 \\
Easy to rear & 24.1 \\
High adaptation & 25.9 \\
Disease resistant & 9.3 \\
High market demand & 61.1 \\
Use tilapia to feed cattish & 7.4 \\
Pond number & \\
<10 & 75.9 \\
10-20 & 18.5 \\
21-30 & 0 \\
31-40 & 1.9 \\
41-50 & 0 \\
>50 & 3.7 \\
Type of fertilizer used & \\
Cow manure & \\
Poultry manure & 55.2 \\
Type of lime used & 44.8 \\
Lime stone & \\
Caustic lime & 54.1 \\
Quick lime & 37.8 \\
Source of water* & 8.1 \\
Streams/rivers & \\
Boreholes & 64.8 \\
Wells & 44.4 \\
\hline "Wultip responses & 7.4 \\
\hline
\end{tabular}

${ }^{*}$ Multiple responses

\section{Management Practices Adopted by Respondents}

Results in Appendix 1 shows that a greater proportion (87.0\%) of the respondents bought feeds from the market, $18.5 \%$ produced their own feeds and $9.5 \%$ bought feeds from other fish farms. This result shows that majority of the respondents cannot produce their own feeds and thus spend much funds purchasing these feeds from the market. Majority $(90.7 \%)$ of the respondents preferred to feed their fish with pelleted feeds while $27.8 \%$ used formulated feed. The preference for pelleted feeds may be attributed to its floating ability and feeds are eaten up before they sink, thus there is less contamination of the 
Creative Commons User License: CC BY-NC-ND

Abstracted by: EBSCOhost, Electronic Journals Service (EJS), Google Scholar, Journal Seek, Scientific Commons,

Food and Agricultural Organization (FAO), CABI and Scopus
Journal of Agricultural Extension

Vol. 23 (3) July, 2019

ISSN(e): 24086851; ISSN(Print); 1119944X

http://journal.aesonnigeria.org

http://www.ajol.info/index.php/iae

Email: editorinchief@aesonnigeria.org

ponds. It is also more common because it is safer and hygienically tested and of international standard though very expensive, which has led to locally formulated feed made by the farmers themselves becoming popular. The locally formulated feed is likely to be very good because the farmers can incorporate appropriate mix of feedstuffs (like vitamins, minerals, soya, molasses, biscuit waste) including drugs. However, formulating this feed is very stressful and there is the possibility of these feeds having high disease potency because of the way they are formulated thereby adversely affecting the fish. Locally made feed is usually not compacted which might make it more suitable for use in earthen pond. This is because the particles are absorbed by the soil unlike the concrete pond or plastic pond where the feeds will cause pollution and regular contamination of the water.

The majority $(85.2 \%)$ of the respondents store their leftover feeds in farm stores in closed containers. Careful storage of fish feed is critical because of the high percentage of unsaturated fatty acids (up to $40 \%$ ) which may become rancid (oxidised) with poor storage or exposure to high temperature. This agrees with Russo and Yanong (2013), who reiterated that in intensive production, feed storage should be critical point to watch out for to prevent application of mouldy foods. About $46 \%$ of the respondents sourced their fingerlings from hatcheries/research centres. Preference for fingerlings from research centres may be due to improvements in genetic qualities of fingerlings. This is contrary to the findings of Igwe and Mgbaja (2014), who reported that fingerlings sourced from fish farms are more likely to be healthier and well bred. Also, about $76 \%$ of the respondents transported fingerlings with open containers, while only about $24 \%$ transported fingerlings in closed containers. The greater use of open containers may be because of the long distances travelled from the hatcheries to the farms.

Appendix 1 further reveals that the majority (72.7\%) of the respondents' market their fishes to wholesalers/retailers who then sell to the consumers, $14.8 \%$ market directly to consumers, while $13.0 \%$ market their fishes to an agent or broker who then sells to wholesalers and or retailers. This suggests uncoordinated market structure which is generally characterised by instability, exploitation of farmers and low economic return for the farmers. Such market structure rarely promotes expansion and sustainable production. Unlike use of cooperatives or market brokers which ensures good and stable price and market.

Appendix 1 shows that $85.2 \%$ of the respondents ensure sufficient supply and timely change of water in their farms. The secret of success in any fish farming operation depends to a large extent, on the ability of the fish farmer to closely manage the pond water by monitoring its physical, chemical and biological properties. According to Bhatnagar and Devi (2013), very transparent water indicates water quality abnormalities like low nutrient level or high acidity making algae unable to survive and unproductive for fish culture, while dark brown coloured water are lethal for fish culture. Light green water shows the presence of algae population which is important even though it should be properly managed to avoid over population as it can have a negative impact. Algae are capable of producing large quantity of oxygen which is very important for the growth and 
Creative Commons User License: CC BY-NC-ND

Abstracted by: EBSCOhost, Electronic Journals Service (EJS), Google Scholar, Journal Seek, Scientific Commons,

Food and Agricultural Organization (FAO), CABI and Scopus
Journal of Agricultural Extension

Vol. 23 (3) July, 2019

ISSN(e): 24086851; ISSN(Print); 1119944X

http://journal.aesonnigeria.org

http://www.ajol.info/index.php/iae

Email: editorinchief@aesonnigeria.org

health of the fish, while consuming carbon dioxide, ammonia and nitrite which can be toxic to the fishes.

About $83 \%$ of the respondents frequently observe their fishes during feeding to cull defective fishes, $80 \%$ treat their ponds before stocking, and $74 \%$ keep resistant breeds of fish and ensure proper feeding formulation. Feed management entails regulating ration size, spatial and temporal dispersal of feed, feed delivery rate and the frequency and duration of feeding events. In ensuring proper feeding, respondents feed pelleted feeds of $2 \mathrm{~mm}-9 \mathrm{~mm}$ in diameter for fish from juvenile to adult stages and $0.2 \mathrm{~mm}-1.5 / 2 \mathrm{~mm}$ from fries to fingerlings every two hours. Also, the respondents feed fish at definite points in the pond as this makes the fish to respond more to feeding spots. The fishes are fed on daily basis before 7.00 am morning and around 6.00 pm evening. Irregular feeding retards the growth rate of fish. This is in line with Apata, (2012) who found that majority of fish farmers in south western Nigeria adopted good feeding technique.

The respondents also carry out some management routines before stocking their pond. First they wash with ordinary water and hard brush, followed by mix of with salt or formalin with water to wash for a second time. After that, they rinse thoroughly and allow drying for an hour, when dried, they pour a litre of formalin and mix it with water and rub on the body of the pond. They leave it for a day so that the sun can dry it up and kill any infection on the body of the pond. Then the following day they pour water and leave it a day to normalize the $\mathrm{pH}$ of water before stocking. Also, they put a bag of salt in the pond and leave it for two to three hours to dissolve and spread. In the hatchery unit, they take utmost care in treating the pond. They use chicken waste, banana or plantain stem, organic waste or manure to fertilise the pond before stocking. The equipment like net, siphoning host, buckets used in the farm, are kept in a solution of formalin and water and used independently for the different ponds so that cross contamination will not occur. 
Creative Commons User License: CC BY-NC-ND

Abstracted by: EBSCOhost, Electronic Journals Service (EJS),

Google Scholar, Journal Seek, Scientific Commons,

Food and Agricultural Organization (FAO), CABI and Scopus
Journal of Agricultural Extension

Vol. 23 (3) July, 2019

ISSN(e): 24086851; ISSN(Print); 1119944X

http://journal.aesonnigeria.org

http://www.ajol.info/index.php/iae

Email: editorinchief@aesonnigeria.org

\section{Perceived Challenges Associated with Fish Farming}

Results in Table 3 show various challenges in fish farming as indicated by the respondents. The major challenges identified were: high cost of feeds $(\bar{x}=2.76)$ and poor

access to formal credit facilities $(\bar{x}=2.17)$. Prices of fish feeds and feed ingredients are always unpredictable. This is attributed to the unstable economic environment of Nigeria. Due to the high cost of imported feeds, many fish farmers are forced into using locally produced feeds which are not up to international standard (Eniola, 2016). Importation of most commercial feeds into the country; stiff government fiscal policies on importation and distribution could be the cause for the hike in feed prices. These commercial feeds possess floating and high protein qualities and are therefore preferred by fish farmers. This is because when farmers feed their fishes with these locally made and in most cases substandard feeds, the fishes do not grow as they are supposed to, leading to great economic losses. Madubuike (2012) reported that high cost of feed is one of the problems of livestock production in Nigeria. Similarly, Sadiq and Kolo (2015); Okpeke and Akarue (2015), identified high cost of feed as very serious drawbacks to profits realized from catfish farming.

Also, fish farming is capital intensive and requires huge capital investment for appreciable profit to be realized. This is in agreement with the findings of Sadiq and Kolo (2015) who reported that feed and labour costs are the major variable expenditures in a fish farming investment. These finding largely agrees with that of Adelodun et al., (2016) who found out that inadequate capital for land acquisition, high cost of quality fish feed and lack of credit facilities are the major constraints hindering the participation of youths in fish production. Unfortunately, most of the loan meant for agricultural development are either diverted or given to office farmers who spend the money on things other than agriculture. However, farmers need working capital for the purchase of production inputs such as fish seed, fingerlings and fish feed; labour for pond preparation and repair; nets and other small equipment for harvesting.

On the other hand, access to affordable land (1.9\%) was not seen as a challenge. This disagrees with the findings of Adedeji and Okocha (2011) that lack of land for pond establishment as one of the constraints to aquaculture. This might be because fish farming does not require much expense of land as farmers can utilize any available empty space in their homes and build them into ponds. Small portions of land can be used to keep the ponds for fish farming and smalls areas can also be dug in case of earthen pond. Once adequate funds are provided for the youths, it will go a long way in annihilating the numerous challenges these respondents are facing.

Table 3: Challenges in fish farming Challenges

Mean Standard

Deviation

High cost of feeds
*2.76

.61 
Creative Commons User License: CC BY-NC-ND

Abstracted by: EBSCOhost, Electronic Journals Service (EJS), Google Scholar, Journal Seek, Scientific Commons,

Food and Agricultural Organization (FAO), CABI and Scopus
Journal of Agricultural Extension

Vol. 23 (3) July, 2019

ISSN(e): 24086851; ISSN(Print); 1119944X

http://journal.aesonnigeria.org

http://www.ajol.info/index.php/iae

Email: editorinchief@aesonnigeria.org

Poor access to formal credits facilities

$\begin{array}{ll}* 2.17 & .91 \\ 1.98 & .84 \\ 1.57 & .72 \\ 1.31 & .64 \\ 1.57 & .82 \\ 1.83 & .77 \\ 1.61 & .79 \\ 1.74 & .85 \\ 1.56 & .72 \\ 1.96 & .88 \\ 1.67 & .80 \\ 1.65 & .76 \\ 1.76 & .78 \\ 1.94 & .76\end{array}$

Difficulty in land acquisition

Inadequate water supply

Poor source of fingerlings

Disease outbreaks

Inadequate/lack of extension services

Poor road network/transportation

Epileptic power supply

Poor storage facilities

Poor access to modern technologies

Scarcity/unstable prices of fingerlings

Inadequate information on management practices

Limited knowledge on diseases and health management in fish

farming

Unavailability of high quality fish feed

1.94

.91

.64

82

.77

.79

.85

.72

.88

.80

.76

78

.76

\section{Conclusion and Recommendation}

The major challenges of fish farming in Abuja were high costs of feed and poor access to formal credit facilities. Subsidies on feed should be provided by the government to encourage existing and prospective youths into the enterprise. Single digit loans should be granted to the farmers to increase their production and productivity.

\section{References}

Adedeji, O.B. and Okocha R.C (2011). Constraint to aquaculture development in Nigeria and way forward. Journal of Applied Sciences Research, 7(7): 1133-1140. Retrieved from https://www.academia.edu/1190268/constraint_to_aquaculture_development_in_n igeria_and_way_forward

Adelodun O. B., Bankole A. F, Rafiu R.A, Morawo B.O. and Ajao F.S (2016). Assessment of youth perception towards fish farming in Ibadan Metropolis. Research Journal of Agriculture and Environmental Management, 5(3); 081-085. Retrieved from http://apexjournal.org/rjaem/archive/2016/Apr/fulltext/Adelodun\%20et\%20al.pdf

Adelodun, O.B. (2015) Participation of youth in aquaculture. Journal of Aquaculture Research and Development,6 (12):386-389. doi:10.4172/2155-9546.1000386

Akinnagbe, O.M \& Adonu, A.U. (2014). Rural farmers sources and use of credit in Nsukka local government area of Enugu state, Nigeria. Asian Journal of AgriculturalResearch, 8 (4): 195-203. DOI: 10.3923/AJAR.2014.195.203.

Apata, O.M. (2012). Awareness and adoption of fish production technologies in south western, Nigeria. Journal of Emerging Trends in Engineering and Applied Sciences (JETEAS). 3(5):819-822.

Bhatnagar, A. \& Devi, P. (2013). Water quality guidelines for the management of pond 
Creative Commons User License: CC BY-NC-ND

Abstracted by: EBSCOhost, Electronic Journals Service (EJS), Google Scholar, Journal Seek, Scientific Commons,

Food and Agricultural Organization (FAO), CABI and Scopus
Journal of Agricultural Extension

Vol. 23 (3) July, 2019

ISSN(e): 24086851; ISSN(Print); 1119944X

http://journal.aesonnigeria.org

http://www.ajol.info/index.php/jae

Email: editorinchief@aesonnigeria.org

fish culture. International Journal of Environmental Sciences, 3(6):19802009. https://doi.org/10.6088/ijes.2013030600019.

Bolonmduro P.I. (2013). Fish culture in ponds. Extension Bulletin No. 103: Fisheries Series No 4. National Agricultural Extension and Research Liaison Services (NAERLS); Zaria.

Dimelu, M.U., Ifeonu, C.F., Asadu, A.N and Ayogu, C.J. (2018). Challenges of disease management in small scale fish farms in Lagos State, Nigeria.Journal of Agricultural Extension, 22 (2): 28-41.https://dx.doi.org/10.4314/jae.v22i2.3

Eniola, A. (2016). Fish Farming in Sub-Saharan Africa: 8 Major Challenges. Retrieved from http://www.profitablefishfarming.com/fish-farming-sub-saharan-africa-8major-challenges/.

Fishery Committee for the West Central Gulf of Guinea (FCWC) (2016). Nigeria fishery statistics - 2016 Summary report. Retrieved from https://www.fcwcfish.org/fisheries/statistics/nigeria/901-nigeria-fishery-statistics-2016-summaryreport on 11th June 2016.

Food and Agriculture Organization (FAO), (2017).Country Profile Fact Sheets. In: FAO Fisheries and Aquaculture Department [online]. Rome. Retrieved from http://www.fao.org/fishery/http://www.fao.org/fishery/facp/NGA/en on 11th June 2019.

Food and Agriculture Organization (FAO), (2018). The State of World Fisheries and Aquaculture 2018 - Meeting the sustainable development goals. Retrieved from http://www.fao.org/3/i9540en/i9540en.pdf

Food and Agriculture Organization (FAO), (2019). FAO in Nigeria: Nigeria at a glance. Retrieved from http://www.fao.org/nigeria/fao-in-nigeria/nigeria-at-a-glance/en/ new

Furlong, A. (2013). Youth studies; an introduction. USA: Routledge. pp 2-3. ISBN 978-0415-56476-2. 6

Igwe, K. C. \& Mgbaja, J. U. (2014). Evaluation of pond fish production in umuahia south local government area of Abia State, Nigeria. Global Journal of Science Frontier Research: D Agriculture and Veterinary, 14 (1): 39-48.

Keremah, R. I, \& Esquire, J. (2014). Comparative assessment of growth performance and economics of production of clarias gariepinus fingerlings in ponds and tanks. Greener Journal of Agricultural Sciences. 4(2):034038, http://dx.doi.org/10.15580/GJAS.2014.2.041513577.

Madubuike F.N. (2012). Bridging the Animal Protein Supply and Demand Gap in Nigeria. Imo State University, Owerri, Nigeria Inaugural Lecture Series No. 7. Imo State 
Creative Commons User License: CC BY-NC-ND

Abstracted by: EBSCOhost, Electronic Journals Service (EJS), Google Scholar, Journal Seek, Scientific Commons,

Food and Agricultural Organization (FAO), CABI and Scopus
Journal of Agricultural Extension

Vol. 23 (3) July, 2019

ISSN(e): 24086851; ISSN(Print); 1119944X

http://journal.aesonnigeria.org

http://www.ajol.info/index.php/jae

Email: editorinchief@aesonnigeria.org

\section{University Owerri}

National Bureau of Statistics (NBS) (2017). Nigeria's Fish Production (2010-2015).

Retrieved

from

ttps://www.proshareng.com/admin/upload/reports/NigeriaFisroductioessed.pdf on $11^{\text {th }}$ June 2019

National Bureau of Statistics (NBS) (2018). Demographic statistics bulletin 2017. Available in

file://C:/Users/Fabsomma/Downloads/Demographic\%20Statistics\%20Bulletin\%20 2017.pdf

Njoku, O. E., Agwa, O. K. \& Ibiene, A. A. (2014). An investigation of the microbiological and physicochemical profile of some fish pond water within the Niger Delta region of Nigeria. African Journal of Food Science, 9(3), pp. 155-162. https://doi.org/10.5897/AJFS2014.1208

Ojiagu, N.C., Onugu, C., \& Uchenna (2015). Effects of membership of cooperative organisations and determinants on farmer members' income in rural Anambra State, Nigeria. International Journal of Scientific \& Technology Research, 4(8), 2835. Retrieved from http://www.ijstr.org/final-print/aug2015/Effects-OfMembershipOf-Cooperative-Organisations-And-Determinants-On-Farmermembers-Income-InRural-Anambra-State-Nigeria.pdf

Okpeke, M. Y. \& Akarue, B. O. (2015). Analysis of the profitability of fish farming in warri south local government area of Delta State, Nigeria. Journal of Agriculture and Veterinary Science, 8 (12): 45-51. Retrieved from http://www.iosrjournals.org/iosrjavs/papers/vol8-issue12/Version-1/l081214551.pdf

Oladimeji, Y.U. (2017).Trend in fish production parameters in Nigeria and its total estimated demand: Empirical evidence from fish production.Journal of Animal Production Research 29(1):410-418. Retrieved from https://www.researchgate.net/publication/319937280_TREND_IN_FISH_PRODUC TION_PARAMETERS_IN_NIGERIA_AND_ITS_TOTAL_ESTIMAT̄ED_DEMAND_ EMPIRICAL_EVIDENCE_FROM_FISH_PRODŪCTION

Oyedeji, F.N. (2016). Assessment of the effects of fish density on growth rate of African catfish (Clarias gariepinus). International Journal of Scientific and Research Publications, 6 (5): 567-570. Retrieved from http://www.ijsrp.org/research-paper0516/ijsrp-p5392.pdf

Russo, J. R. and Yanong, R.P.E. (2013). Molds in fish feeds and aflatoxicosis. School of Forest Resources and Conservation, Program in Fisheries and Aquatic Sciences, UF/IFAS Extension. Fact Sheet FA-95. Retrieved from ttps://agrilifecdn.tamu.edu/fisheries/files/2013/09/Molds-in-Fish-Feeds-andAflatoxicosis.pdf 
Creative Commons User License: CC BY-NC-ND

Abstracted by: EBSCOhost, Electronic Journals Service (EJS), Google Scholar, Journal Seek, Scientific Commons,

Food and Agricultural Organization (FAO), CABI and Scopus

http://eoi.citefactor.org/10.11226/v23i3
Journal of Agricultural Extension

Vol. 23 (3) July, 2019

ISSN(e): 24086851; ISSN(Print); 1119944X

http://journal.aesonnigeria.org

http://www.ajol.info/index.php/jae

Email: editorinchief@aesonnigeria.org

Ryota H., Munehiro Y., and Kenji F. (2012). Seafood consumption and components for health. Global Journal of Health Science, 4(3): 72-86. doi: 10.5539/gjhs.v4n3p72

Sadiq, M. S. and Kolo, M. D. (2015). Problems' and prospects of small-scale fish farming in Minna Agricultural Zone of Niger State, Nigeria, and its implications on increased Fish Food Security. International Journal of Agricultural Research and Review,3(2): 157-160. Retrieved from http://www.springjournals.net/fullarticles/springjournals. netijarrarticlesindex=4sadiqandkolo.pdf?view=inline

Thomas, K.A., \& Eforuoku, F. (2016). Determinants of participation in Youth-in-Agriculture Programme in Ondo State, Nigeria. Journal of Agricultural Extension, 20(2). http://dx.doi.org/10.4314/jae.v20i2.8

\section{Appendix 1: Management practices adopted by the respondents *Multiple responses}

\begin{tabular}{ll}
\hline Management practices & Percentage (\%) \\
\hline Sources of feed & 18.5 \\
Own farm & 9.3 \\
Other farms & 87.0 \\
Market & \\
Feed types & 90.7 \\
Pelleted feed & 27.8 \\
Formulated feed & 3.7 \\
Kitchen waste & 18.5 \\
Blood meal & 7.4 \\
Animal offal & 3.7 \\
Agric by-product & \\
Feed storage & 5.6 \\
Do not store feed & 9.3 \\
open containers & 85.2 \\
farm store in closed containers & \\
Source of fingerlings* & 33.3 \\
Other fish farms & 46.3 \\
Hatcheries/research centres & 29.6 \\
Self-breeding & \\
Transportation of fingerlings & 75.9 \\
open containers & 24.1 \\
closed containers & \\
Marketing channel &
\end{tabular}


Creative Commons User License: CC BY-NC-ND

Abstracted by: EBSCOhost, Electronic Journals Service (EJS),

Google Scholar, Journal Seek, Scientific Commons,

Food and Agricultural Organization (FAO), CABI and Scopus

http://eoi.citefactor.org/10.11226/v23i3
Journal of Agricultural Extension

Vol. 23 (3) July, 2019

ISSN(e): 24086851; ISSN(Print); 1119944X

http://journal.aesonnigeria.org

http://www.ajol.info/index.php/jae Email: editorinchief@aesonnigeria.org

Farm to consumer

14.8

Farm to wholesaler/retailer

72.2

Farm to agent/broker to wholesaler

Other management practices

Ensuring sufficient supply of clean water and timely change of water

Frequent observation during feeding to cull defective fishes

83.1

Treatment of pond before stocking

79.6

Keeping of resistant breed

74.1

Proper feeding formulation

74.1

Keeping different sizes of fish separately to control fighting

Handling fishes with care and minimal disturbances especially during sorting and grading to prevent injuries.

Covering of the ponds with net to control fish-eating predators

70.4

Purchasing of fingerlings from a reliable source

Quarantine fish before stocking

Maintenance of optimum water $\mathrm{pH}$

Regular cleaning and disinfection of ponds

Disinfection of fingerlings before stocking them

Having separate equipment for handling small and large fishes in a pond 